\title{
Augmentation of Groundwater Resources through Watershed Management: An Overview
}

\author{
S.K.Maanju*,K.Saha**,R.K.Verma*** \\ * S.S. in Earth Science, Vikram university, Ujjain (MP) \\ **Govt. Dungar college, Bikaner. \\ ***St.Wilfred's P.G.College,Jaipur.
}

\begin{abstract}
There is growing stress on the water resource availability all over the globe. The population rise, unplanned day by day increasing urbanization, multiplicity of Industrial activities, modernizing agriculture and overall inefficient water use practices has further worsened the availability of water resources. Since water mass is constant throughout hydrological cycle, therefore, we should focus on efficient water resource management. The present paper discusses the pattern of water distribution and importance of watershed management.
\end{abstract}

Key words: Watershed, Groundwater, Environment.

\section{Introduction}

As per an estimate the total water in the world is 1.5 billion cubic kilometers and $95 \%$ of which is in salty areas and thus remaining 5\% (75 million cubic $\mathrm{km}$ ) is fresh water and out of this, 60 million cubic kms. constitute solid form, leaving only 15 million cubic $\mathrm{km}$ as fresh liquid water for organic world. Only $1 \%$ fresh water is surface water and 99\% remaining fresh water is stored beneath the surface of the earth at varying depths. About half of ground water is considered to be stored at depths greater than $1000 \mathrm{mts}$. and accordingly not feasible to pump for human use. In this way only 7 million cubic kms of fresh ground water entrapped at reasonable depths from surface plus 15000 cubic kms surface water is only useable water available in the world. The distribution of world water is tabulated below as table- 1 whereas annual water balance is shown in table-2.The precipitation and the run-off relation among all the continents is shown in table3 as well as annual run-off of world rivers into sea is shown in table-4. The rate of water exchange in hydrologic cycle during the year is shown in table- 5 alongwith water carried by ocean currents and intensity of water exchange is shown in table-6

Table-1 (Nace 1960 and Feth 1973 )

\begin{tabular}{|l|l|l|}
\hline \multicolumn{1}{|c|}{ Content } & \multicolumn{1}{|c|}{ Volume in $1000 \mathrm{~km}^{3}$} & \multicolumn{1}{c|}{$\%$ of total water } \\
\hline Atmospheric water & 13 & 0.001 \\
Surface water & 1320,000 & 97.219 \\
Salt water in oceans & 104 & 0.008 \\
Salt water in lakes and Inland seas & 125 & 0.009 \\
Fresh water in Lakes & 1.25 & 0.0001 \\
Fresh water in stream channels & 29,000 & 2.136 \\
Fresh water in glaciers and Ice caps & 50 & 0.004 \\
Water in the Bo-mass & 67 & 0.005 \\
Sub-surface water & 4,200 & 0.309 \\
Vadose water & 4200 & 0.309 \\
Groundwater within depth of $0.8 \mathrm{~km}$ & & 100 \\
$\quad$ (active exchange) & $13,57,760$ & \\
Groundwater between 0.8 and 4km depth & & \\
\hline Total & & \\
\hline
\end{tabular}

Table-2 Annual water Balance of the World (Lvovich 1973)

\begin{tabular}{|c|c|c|}
\hline Item & $\begin{array}{c}\text { Volume } \\
\text { (cubic kilometers) }\end{array}$ & $\begin{array}{c}\text { Depth } \\
\text { (millimeters) }\end{array}$ \\
\hline $\begin{array}{l}\text { 1.Periphery of Land Area }\left(116.8 \times 10^{6}\right. \\
\left.\text { km }^{2}\right)\end{array}$ & & \\
\hline Precipitation & 106,000 & 910 \\
\hline River discharge & 41,000 & 350 \\
\hline Evaporation & 65,000 & 560 \\
\hline 2.Inland Water $\operatorname{Area}\left(32.1 \times 10^{6} \mathrm{~km}^{2}\right)$ & & \\
\hline Precipitation & 7,500 & 238 \\
\hline $\begin{array}{l}\text { Evaporation } \\
\text { 3. World Ocean Area }\left(36.1 \times \mathbf{1 0}^{6} \mathbf{k m}^{2}\right)\end{array}$ & 7,500 & 238 \\
\hline
\end{tabular}




\begin{tabular}{|l|r|r|}
\hline Precipitation & 411,600 & 1,140 \\
Inflow of river water & 41,000 & 111 \\
$\quad$ Evaporation & 452,600 & 1,251 \\
4. World Total Area(510 x $\left.\mathbf{~ 1 0}^{\mathbf{6}} \mathbf{~ k m}^{\mathbf{2}}\right)$ & & \\
$\quad$ Precipitation & 525,100 & 1,030 \\
Evaporation & 525,100 & 1,030 \\
& & \\
\hline
\end{tabular}

Table-3 Precipitation-Run-off Relation of the Continents (Lvovich 1973)

\begin{tabular}{|c|c|c|c|c|c|c|c|c|c|}
\hline \multirow[t]{2}{*}{ Continents } & \multirow[t]{2}{*}{$\underset{10^{6} \mathrm{~km}^{2}}{\text { Area }}$} & \multicolumn{2}{|c|}{$\begin{array}{c}\text { Annual } \\
\text { Precipitation }\end{array}$} & \multicolumn{2}{|c|}{ Evaporation } & \multicolumn{2}{|c|}{ Overland surface Run-off } & \multicolumn{2}{|c|}{$\begin{array}{c}\text { Groundwater } \\
\text { Flow }\end{array}$} \\
\hline & & $\mathrm{Mm}$ & $\mathrm{Km}^{3}$ & $\begin{array}{l}\mathrm{Km}^{3} \\
\text { Precipi }\end{array}$ & $\begin{array}{l}\mathbf{f} \\
\text { on }\end{array}$ & & & $\begin{array}{l}\mathbf{K m}^{\frac{1}{3}} \\
\text { Prec }\end{array}$ & $\begin{array}{l}\% \text { of } \\
\text { ation }\end{array}$ \\
\hline Asia & 45 & 726 & 32,690 & 19,500 & 59.0 & 9,780 & 29.9 & 3,410 & 10.5 \\
\hline Europe & 9.8 & 734 & 7,165 & 4,055 & 56.5 & 2,045 & 28.6 & 1,065 & 14.9 \\
\hline Africa & 30.3 & 686 & 20,780 & 16,555 & 79.7 & 2,760 & 13.3 & 1,465 & 7.0 \\
\hline North America & 20.7 & 670 & 13,910 & 7,950 & 57.2 & 4,220 & 30.3 & 1,740 & 12.5 \\
\hline South America & 17.8 & 1640 & 29,355 & 18,975 & 64.6 & 6,640 & 22.6 & 3,740 & 12.8 \\
\hline Australia & 8.7 & 736 & 6,405 & 4,400 & 69.7 & 1,500 & 23.4 & 465 & 7.3 \\
\hline All land areas & 132.3 & 834 & 110,305 & 71,465 & 64.7 & 26,945 & 24.4 & 11,885 & 10.8 \\
\hline
\end{tabular}

Table-4 Annual run-off World Rivers into sea (Lvovich 1973)

\begin{tabular}{|l|c|c|}
\hline \multicolumn{1}{|c|}{ Region } & Run-off volume $\mathbf{~ k m}^{\mathbf{3}}$ & Depth(mm) \\
\hline 1.Asia & 13,190 & 293 \\
2.Europe & 3,110 & 319 \\
3.Africa & 4,225 & 139 \\
4.North America & 5,960 & 287 \\
5.South America & 10,380 & 585 \\
6.Australia & 1,965 & 226 \\
7.Greenland & 700 & 180 \\
8.Antarctica & 2,200 & 250 \\
& & \\
\hline Total & & 280 \\
\hline
\end{tabular}

Table-5 Rate of water Exchange in Hydrologic Cycle during the Year

\begin{tabular}{|l|c|c|}
\hline \multicolumn{1}{|c|}{ Hydrologic Arc } & Activity & $\begin{array}{c}\text { Quantity in } \\
\text { Active exchange in } \mathbf{~ k m}^{\mathbf{3}}\end{array}$ \\
\hline World Ocean & Circulation & 452,600 \\
Ground water & Circulation & 1,200 \\
Polar glacier & Circulation & 2,900 \\
River water & Circulation & 41,000 \\
\hline
\end{tabular}

Table-6 Water carried by Ocean currents and Intensity of Water Exchange(Lvovich 1973-p26)

\begin{tabular}{|c|c|c|c|c|}
\hline Oceans & Area in million sq.km & $\begin{array}{c}\text { Volume in million } \\
\text { cu.km }\end{array}$ & $\begin{array}{c}\text { Annual flow in million } \\
\text { cu.km }\end{array}$ & $\begin{array}{c}\text { Water exchange } \\
\text { intensity ratio of } \\
\text { annual flow to ocean } \\
\text { volume } \\
\text { (No. of years) }\end{array}$ \\
\hline Pacific & 180 & 725 & 6.56 & 110 \\
Atlantic & 93 & 338 & 7.30 & 46 \\
Indian & 75 & 290 & 0.44 & 39 \\
Arctic & 13 & 17 & 21.70 & 63 \\
World Ocean & 363 & 1,370 & & \\
\hline
\end{tabular}

India with a geographical area of 328 million ha. received rainfall varying from $100 \mathrm{~mm}$ in western Rajasthan and exceeding $11000 \mathrm{~mm}$ in Chirapunji in Meghalaya experiences extremes of climate. The average annual rainfall of the country is about $1170 \mathrm{~mm}$ which constitute average run off of 1869 cubic $\mathrm{km}$ in river systems. During the monsoon period over $90 \%$ run off occur in peninsular rivers whereas $80 \%$ of the annual run off in the Himalayan rivers.

Average annual rainfall over India is computed as $117 \mathrm{~cm}$ which is largest anywhere in the world for a country of a comparable size, the global mean being $99 \mathrm{~cm}$.the annual rainfall suffers from wide departure from the normal from year to year. Rainfall in India is erratic and Ill-distributed. It varies from place to place and year to year. While western Ghats, Assam and its neighborhood and parts of Himalayas receive more than $200 \mathrm{~cm}$ annually; in contrast Rajasthan, Kuttch receive rainfall between $10 \mathrm{to} 50 \mathrm{~cm}$ in a year. Chirapunji records 
a rainfall of $1142 \mathrm{~cm}$, the highest in the country in a year and recorded as high as $104 \mathrm{~cm}$ in one day .In major parts of the country almost 85 to 90 percent of the total rainfall is contributed by the southwest monsoon and is received only in four rainy months of June to September .The balance precipitation occurs during the NorthEast monsoon period of November and December mostly in the coastal area of Tamilnadu, Andhra Pradesh and parts of Orissa. There is wide departure in rainfall from year to year even in the rainy season. The rainfall in most part of the country is subject to uncertainty of occurrence marked by prolonged dry spell and aberration in time of commencement and with drawl and also the total amount received. Considering the nature of topography of the country, concentration and localized precipitation in the regions only limited extent of surface stream flow could be availed and rest goes into the sea.

Annual average precipitation in India $=370 \times 10^{6}$ ha.m

Loss in evaporation

Loss in seepage to soil

Annual stream flow in river

$=120 \times 10^{6}$ ha.m

$=80 \times 10^{6}$ ha.m. (Groundwater $40 \times 10^{6}$ ha.m)

$=170 \times 10^{6}$ ha.m. (utilizable flow $77 \times 10^{6}$ ha.m)

Thus surface water source is about $21 \%$ and groundwater source is about $11 \%$ of the annual precipitation.

\section{STATUS OF WATER UTILIZATION IN INDIA}

In our country the main occupation of the people is agriculture and presently the irrigated area in the country is more than 91.8 million ha including 33.82 million ha from major and medium project. In 1997 total utilization of surface and ground water was about 605 cubic $\mathrm{km}$. It is estimated that by 2025 , the total water utilization in the country is projected about 1050 cubic $\mathrm{km}$ (700 cubic $\mathrm{km}$ from surface and 350 cubic $\mathrm{km}$ from ground water). This includes 52 cubic $\mathrm{km}$ for domestic use, 770 cubic $\mathrm{km}$ from irrigation, 71 cubic $\mathrm{km}$ for energy, 120 cubic $\mathrm{km}$ for industrial and 37 cubic $\mathrm{km}$ for other purposes. Thus, it appears that almost the entire utilizable water resources would be required to be utilized completely by 2025 .

The available fresh water source is being depleted day by day which has led rationing of water in urban areas. Inter State and Inter City disputes on the use of water are growing day by day and even International disputes on water are getting space as box items on the first page of leading news papers of the world. The increasing population of India needs more water not only for personal and domestic use but requires more and more for irrigation to cater proportionate food demand.

Per capita average annual availability of water in world is 8500 cubic meters whereas in India annual water resources in the various river basins are estimated to be around 1869 cubic $\mathrm{km}$ and per capita annual availability is only 2200 cubic km which is not even uniform in the country. It varies from 18417 cubic mts. in Brahmaputra to as low as 380 cubic mts in some rivers of Tamilnadu. In any situation if availability is less than 1000 cubic mts. then, annually scarcity conditions are considered by International Agencies in that area. Thus, it is emerged that remedial measures are to be taken since water scarcity conditions are already prevailing in our country.

\section{WATERSHED}

Watershed Management Programme has to be adopted for conservation of soil and water in order to get optimum results. The term "watershed" indicates a geo- hydrological unit comprising of all land and water within the confines of drainage divide. The size of watershed in increasing order is expressed by terms such as micro-watershed, sub-watershed, watershed catchments and river basin. Watershed Management is an integrated approach to the development of an area with the ultimate aim of improving the quality of the life of the inhabitants of the area.

\section{MAIN OBJECTIVES OF WATERSHED MANAGEMENT}

The ultimate aim of watershed management programme is to protect and improve the quality of life of the community. In order to achieve this objective there are several sub objectives which are required to be operated simultaneously as under:

1. Conservation of basic natural resources like soil, water and vegetation.

2. Protection of environment and restoration of geological balance.

3. Sustainable crop yields by adopting improved management and farming practices.

4. Development of land use systems through horticulture, forestry, pasture and animal husbandry.

5. Training programmes are to be conducted from time to time to educate beneficiaries and enhance their capacity and skill.

6. Regular periodical assessment by concerned people of watershed programme is essential for better results.

7. The awareness of people both as participant directly within the watershed area and as a beneficiary from the conservation of soil and water particularly for domestic purposes is essential. 


\section{Conclusion}

Theoretically we know that the water mass transfer takes place through various components of hydrologic cycle with mass balance remaining the constant. However, with intended interventions in the systems, it is possible to beneficially divert several times more water than it is actually in the form of developed water supplies. The hurdle in utilization of rain water is non- availability of storage facilities since major quantity of river water goes in flood flows which is approximately $20 \%$ of total precipitation. Another factor of Inter- state water disputes also put difficulties since water is a state subject. Recently Central Ground Water Board has assessed that 432 cubic $\mathrm{km}$ of groundwater is available annually through conventional means which could be utilized for replenishing existing water level whereas as per an estimate 690 cubic $\mathrm{km}$ water could actually be utilized by constructing water harvesting structure.

International Water Management has indicated that by $2055,40 \%$ of the world population will live in constraint with physical water scarcity and $26 \%$ will live in constraint with economic scarcity. In this background it is very timely that we geoscientist should devise, formulate strategies towards finding suitable remedy for the present and the impending water crisis, the degree/intensity of which would go on increasing if timely thinking/measures are not carried out.

It has been found out that in 2055 , the world will need at least $27 \%$ more developed water supplies for all sectors including $60 \%$ more water for irrigation. Although this increase is only about $1 \%$ per year, it is still represents 490 cubic $\mathrm{km}$ water per year. However, the picture may not be so gloomy if we are able to put our collective efforts and wisdom to resolve the issues. It is possible to have a blue revolution in water after having gone through successfully various similar revolutions such as white, green revolution and so on. The answer is an effective Watershed Management Approach aided with water recycling and precision irrigation as the watershed is the source of all our surface and subsurface water resources.

\section{Reference}

[1]. Bouwer, H 1978 Ground water hydrology, Mc Grow Hill, New-York.

[2]. Davis D.N. and Dewiest, R.J.M. 1968 Hydrogeology John Willey \& Sons

[3]. Garg, S.K. 1973. Water resources and Hydrology. Khanna publishers Nai Sadak, Delhi.

[4]. Heath R.C. and Frenk W. Trainer 1968. Introduction of ground water hydrology. John Willey \& Sons, New-York

[5]. Jhanwar, M.L., 1998. Hydrology and water Resources. published by Vigyan Prakashan Bapu Nagar, Jodhpur.

[6]. Karanth, K.R., 1989. Hydrogeology. Tata Mc Graw Hill Publishing Company Limited Asaf Ali Road, New Delhi.

[7]. Nagabhushaniah ,H.S.2001.Groundwater In Hydrosphere CBS Publishers \& Distribtors, New Delhi.

[8]. Todd, D.K. 1980. Ground water hydrology, John. Willey \& Sons, New- York.

[9]. Walton, W.C. 1970. Ground water resource evaluation Mc Graw Hill, New-York. 